
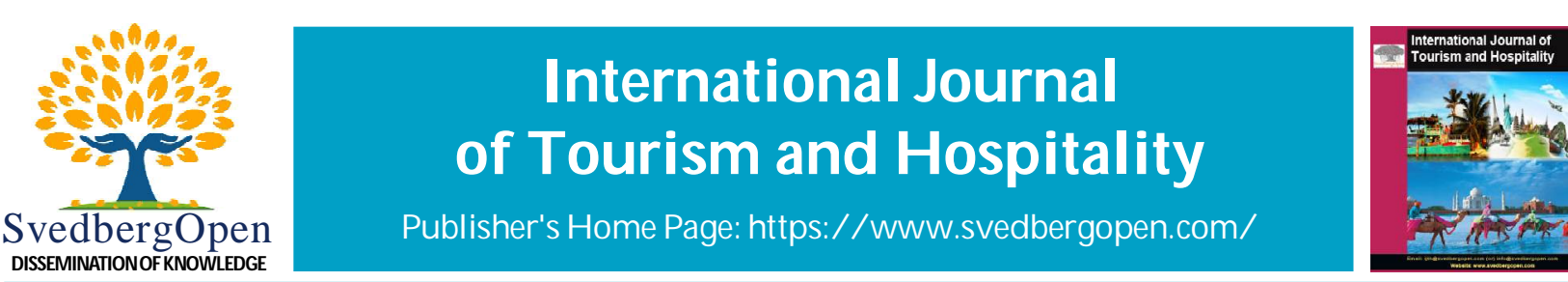

Research Paper

\title{
Impacts of the Use of Water Hyacinths as a Form of Livelihood Programs in the Local Residents of Taguig City: Inputs for Tourism Entrepreneurship
}

\begin{abstract}
Anissa Kyla R. Abenoja ${ }^{1}$, Bryan Ivan A. Cleofe ${ }^{2}$, Nicole Anne R. Mondero ${ }^{3}$, Paula N. Rodriguez ${ }^{4}$ and Jefferson S. Marcelo
${ }^{1}$ College of International Tourism and Hospitality Management, Lyceum of the Philippines University Manila. E-mail: anissa.abenoja @lpunetwork.edu.ph ${ }^{2}$ College of International Tourism and Hospitality Management, Lyceum of the Philippines University Manila. E-mail: bryan.cleofe@lpunetwork.edu.ph ${ }^{3}$ College of International Tourism and Hospitality Management, Lyceum of the Philippines University Manila. E-mail: nicole.mondero@lpunetwork.edu.ph ${ }^{4}$ College of International Tourism and Hospitality Management, Lyceum of the Philippines University Manila. E-mail: paula.rodriguez@lpunetwork.edu.ph ${ }^{5}$ College of International Tourism and Hospitality Management, Lyceum of the Philippines University Manila. E-mail: jefferson.marcelo@lpu.edu.ph
\end{abstract}

\section{Article Info}

Volume 1, Issue 4, October 2021

Received : 15 June 2021

Accepted : 17 September 2021

Published : 05 October 2021

doi: 10.51483/IJTH.1.4.2021.23-29

\begin{abstract}
Water hyacinths have severely infested Philippine waters with their rapid rate of proliferation. It is the foremost damaging vascular plant worldwide because of its capability to breed at rare rates, thereby choking lakes and rivers. Subsequently, the regional city government has provided a vocation course and preparing on contriving and production of bayong and distinctive painstaking work made out of water hyacinths to several barangays, networks/communities, groups, associations, students, school authorities, instructors, nongovernment organizations, as well as religious groups. Thus, the study is aimed to determine the effect of the utilization of water hyacinths as a type of livelihood program that benefits the local residents of Taguig city. This research employed a quantitative descriptive method and research made survey questionnaire as a survey instrument that was used based on the different literature and studies gathered related to the study. The study population was selected within the three (3) barangays, namely Barangay Wawa, Barangay Sta. Ana, and Barangay Bambang, along with its respondents ranging from 30-35 constituents in each barangay through snowball sampling. The findings present that the water hyacinths livelihood program is beneficial to the residents of three barangay and advantageous to the environment of the City of Taguig. It has been considered as an employment generation program for the residents, particularly near the site of the shop, in making water hyacinth products. Furthermore, it has also been valuable to the economic dynamism of the City of Taguig since it helps boost their household earnings.
\end{abstract}

Keywords: Water hyacinths, Recognize, Impact, Benefit

(C) 2021 Anissa Kyla R. Abenoja et al. This is an open access article under the CC BY license (https://creativecommons.org/licenses/by/4.0/), which permits unrestricted use, distribution, and reproduction in any medium, provided you give appropriate credit to the original author(s) and the source, provide a link to the Creative Commons license, and indicate if changes were made.

\section{Introduction}

As defined by Dersseh et al. (2019), water hyacinths are a type of flowering invasive tracheophyte plant. This plant has caused disruption in many countries, including the Philippines. The water hyacinth has been proven to have many negative impacts on the ecosystem, such as the increase in the evapotranspiration of lake water, which then affects Lake Hydrology. However, the application of water hyacinths can be diverse within other aspects, which is substantial for the initiation of livelihood programs.

\footnotetext{
* Corresponding author: Jefferson S. M arcelo, College of International Tourism and Hospitality M anagement, Lyceum of the Philippines U niversity M anila. E-mail: jefferson.marcelo@lpu.edu.ph
} 
As per Metropolitan Manila Development Authority (MMDA), water hyacinth has caused the city to flood. Thick hyacinth beds similarly shield sunlight from rapidly entering into the waters, meagering ("lanta") lowered plants and the fish and other maritime life outlines that depend upon them (Melican, 2012). Moreover, it can damage vascular plants that are present in many lakes and rivers with its rapid rate of reproduction. When water hyacinths obstruct these bodies of water once it is introduced, which grows in mats up to 2 meters wide. This large area causes a reduction in light and oxygen, a change in water chemistry, and possibly may affect local flora and fauna. Water hyacinths had made water practices unpredictable, illogical, and made huge hydropower arrangements suffer due to the ceased upstreams. Fishing openings result in various complexities in terms of functionality. When there is a weed invasion, water begins to lose light and oxygen, which clarifies the overall of the fish vanishes.

In terms of the specific area to be explored, Taguig city is a first-class, highly urbanized city from the National Capital Region (NCR) of Luzon, Philippines (Philippine Statistics Authority, 2015), where scarcity occurs within the major commercial core. The city government gave a vocational course to prepare, contrive, and produce bayong and distinctive painstaking work made out of water hyacinths to several barangays, networks/communities, groups, associations, students, school authorities, and non-government organizations, as well as religious groups.

The main problem Taguig Citizens encounter is the increasing numbers of water hyacinth clogging the metro waterways and elsewhere. However, the water hyacinth can essentially be an excellent material for novel products that can churn in income for individuals and the community. According to Tadili (2012), a machine has been developed by engineers of the Metals Industry Research and Development Center (MIRDC) of DOST to cope with the adverse effects of water lilies present in the Philippine waterways. Based on the description, the harvester is a small-sized vessel that mechanically collects free-floating water hyacinths that congest waterways. The DOST has confirmed that the machine is only the starter approach to the solution. It aims to continue developing new technologies so that water orchids can serve a better purpose in different industries, such as being used for biogas, animal feeds, and geotextiles.

\section{Objectives of the Study}

Hence, this research is designed to identify the impact of the water lily livelihood program initiated by the city government on local residents. The objectives of the researchers are to be aware of the benefits we can get from water lilies and generate jobs for the locals in order to know the satisfaction of the employees in the water hyacinth livelihood program.

\section{Materials and Methods}

This study employed a quantitative descriptive method as it described the characteristic of the respondent, the evaluation of the impact of the water hyacinth livelihood program, and the problem that will be encountered in the use of water hyacinth as a form of livelihood as inputs to tourism entrepreneurship. Quantitative research can be used for predictions, treat causal relationships, and general results to a wider population, which seeks an overall summary of variables within the study.

In terms of the sample size, the population was subcategorized according to the respondents ranging from 30-35 within three (3) barangays each, namely Barangay Wawa, Barangay Sta. Ana, and Barangay Bambang. The researcher used the snowball sampling technique, a non-probability in gathering the data for this study, wherein the respondents will be asked to recruit other participants as part of strengthening this study.

A public opinion survey was the technique used by the researchers to analyze and interpret the data to come up with findings, conclusions, and recommendations. The research-made survey questionnaire is divided into four parts. The first part is the demographic profile of the respondents; it was subcategorized according to age, gender, civil status, monthly income, barangay, and employment status. Second, the impact of the water hyacinth livelihood program on the community regarding social, economic, and environmental is tackled, which comprised of five (5) questions each.

The instrument will be validated by internal and external experts in the field of tourism. A validation instrument will be sent to the experts and draw feedback. From their feedback, the researcher will revise the instrument. Moreover, the instrument was required to seek an answer from the respondents of 3 Barangays and pretest the questionnaire in order to check the comprehensibility of the questionnaire. The responses made by the participants are gathered and analyzed through the following statistical tools, involving the percentage and weighted mean of the various aspects that were tackled in the questionnaires.

\section{Results and Discussion}

Table 1. The impact of water hyacinths as a form of livelihood programs in terms of social rated as Strongly Agree with an overall weighted mean of 3.32 . 
Table 1: The Impact of Water Hyacinths as a Form of Livelihood Programs in Terms of Social Aspects

\begin{tabular}{|cl|c|c|c|}
\hline \multicolumn{2}{|c|}{ Indicators } & Weighted Mean & Verbal Interpretation & Rank \\
\hline $1.1 \quad \begin{array}{l}\text { The water lily livelihood program is in line with the } \\
\text { community goals which is to create employment } \\
\text { opportunities with economic growth. }\end{array}$ & 3.54 & Strongly Agree & 1 \\
\hline $1.2 \quad \begin{array}{l}\text { Wealth in the community when the water lily } \\
\text { livelihood program started. }\end{array}$ & 3.39 & Strongly Agree & 2 \\
\hline $1.3 \quad \begin{array}{l}\text { Unemployment in the community when the water lily } \\
\text { livelihood program started. }\end{array}$ & 3.10 & Strongly Agree & 3 \\
\hline $\begin{array}{l}\text { The program opens the local community consultation } \\
\text { for new programs. }\end{array}$ & 3.32 & Strongly Agree & 4 \\
\hline $\begin{array}{l}\text { The program affected the social status of the community } \\
\text { which leads to the community progressing. }\end{array}$ & 3.27 & Strongly Agree & 5 \\
\hline
\end{tabular}

Four (4) items are rated strongly agree it is in line with the goal of the community, which is to create employment opportunities with economic growth with a composite weighted mean of 3.54 as rank 1; Wealth in the community when the water lily livelihood program started with a composite weighted mean of 3.39 as rank 2; it opens the local community consultation for new programs with a composite weighted mean of 3.32 as rank 3; The program affected the social status of the community which leads to the community progressing with composited weighted mean of 3.27 as all rank 4; Unemployment in the community when the water lily livelihood program started is rank the lowest as Agree with a composite weighted mean of 3.10 as rank 5 .

It means the impact of water hyacinths is literate in terms of positive programs but not to the idea of unemployed since it is the least rank among all the indicators. The findings also imply that the majority of the respondents look into the community goals. According to DOST (Department of Science and Technology, 2012), Water Hyacinth Harvester Machine makes it easier to harvest the water hyacinth. Mechanically method is much better than harvesting by chemical methods but hazardous to the animals and plants. DOST Secretary Mario Montejo says that the machine can be modified and enhanced depending on the need or the size of the water. They are also open to improving the machine in the near future.

Table 2. The impact of water hyacinths as a form of livelihood programs in terms of economy rated as Agree with an average weighted mean of 3.09 .

Table 2: The Impact of Water Hyacinths as a Form of Livelihood Programs in Terms of Economy

\begin{tabular}{|cl|c|c|c|}
\hline \multicolumn{1}{|c|}{ Indicators } & Weighted Mean & Verbal Interpretation & Rank \\
\hline $2.1 \quad \begin{array}{l}\text { I can now provide enough foods to my family because } \\
\text { my monthly income increases. }\end{array}$ & 3.13 & Agree \\
\hline 2.2 & $\begin{array}{l}\text { I receive additional responsibility in my job which results } \\
\text { to additional pay. }\end{array}$ & 2.89 & Agree & Strongly Agree \\
\hline $2.3 \quad \begin{array}{l}\text { The water lily livelihood program boosts the families } \\
\text { household earnings. }\end{array}$ & 3.37 & Agree & 3 \\
\hline 2.4 & $\begin{array}{l}\text { I receive more benefits from the community government } \\
\text { because of the program. }\end{array}$ & 3.02 & Agree & 4 \\
\hline $\begin{array}{l}\text { We received weekly trainings/seminars to improve the } \\
\text { program. }\end{array}$ & 3.09 & Agree & \\
\hline
\end{tabular}


One item is rated as Strongly Agree, namely; it boosts the families household earnings with a composite weighted mean of 3.37 as rank 1; and other items are rated as Agree namely: 'I can now provide enough foods to my family because my monthly income' increases with 3.13 mean and rank 2, 'I receive more benefits from the community government because of the program' with composite mean 3.02 as well as 'We received weekly trainings/seminars to improve the program' with rank 3 and 4 respectively. According to Amy M Villamagna (2010), the economic cost of controlling water hyacinth infestations is a function of the rate of removal, labor costs, equipment costs, and the frequency of treatment. Based on the extent of the infestation and the type of control used, each of these factors will differ.

Table 3. The impact of water hyacinths as a form of livelihood programs in terms of environmental as Strongly Agree with an average weighted mean of 3.45.

Table 3. The Impact of Water Hyacinths as a Form of Livelihood Programs in Terms of Environmental

\begin{tabular}{|c|c|c|c|}
\hline \multicolumn{1}{|c|}{ Indicators } & Weighted Mean & Verbal Interpretation & Rank \\
\hline $3.1 \quad \begin{array}{l}\text { I became aware of the advantages of water lily on the } \\
\text { environment. }\end{array}$ & 3.56 & Strongly Agree & 3 \\
\hline $3.2 . \quad \begin{array}{l}\text { I was informed that water lily has a negative impact on } \\
\text { the environment like climate change. }\end{array}$ & 3.11 & Agree & 2 \\
\hline $3.3 \quad \begin{array}{l}\text { The program contributes to the improvement of the } \\
\text { environment. }\end{array} \quad$ The program complies with the environmental standards. & 3.32 & Strongly Agree & 4 \\
\hline $3.4 \quad$ The program has positive impacts in the environment. & 3.67 & Strongly Agree & 1 \\
\hline $3.5 . \quad$ AVERAGE WEIGHTED MEAN & 3.45 & Strongly Agree & \\
\hline
\end{tabular}

One item was rated Agree: 'I was informed that water lily has a negative impact on the environment like climate change,' which has a composite mean of 3.11 and ranks as \#5. Four (4) items were rated Strongly Agree, namely: 'The program has positive impacts in the environment,' which has a composite mean of 3.67 and rank 1, 'The program contributes to the improvement of the environment,' which has a composite mean of 3.57 and rank as 2, 'I became aware of the advantages of water lily on the environment' with a composite mean of 3.56 which is rank 3 and last one is 'The program complies with the environmental standards' with composite mean 3.32 rank 4.

Haider (1989) discussed that Water Hyacinth could be used not only to purify water for drinking but for other water uses. Water hyacinth can assist in cleaning the water as a pretreatment step of purification. With the elimination of small flocks, healthy plants will help. The water hyacinth may also be used for the removal of organic compounds from heavy metals.

Table 4. The impact of water hyacinths as a form of livelihood programs in terms of social, economic, and environmental.

Table 4: Summary of the Impact of Water Hyacinth as a Form of Livelihood Program

\begin{tabular}{|cl|c|c|c|}
\hline \multicolumn{1}{|c|}{ Indicators } & Weighted Mean & Verbal Interpretation & Rank \\
\hline $1 . \quad$ Social & 3.32 & Strongly Agree & 2 \\
\hline $2 . \quad$ Economic & 3.09 & Agree & 3 \\
\hline $3 . \quad$ Environmental & 3.45 & Strongly Agree & 1 \\
\hline \multicolumn{2}{|c|}{ AVERAGE WEIGHTED MEAN } & 3.29 & Strongly Agree & \\
\hline
\end{tabular}


It shows that the environmental aspect is the priority among other variables with a weighted mean of 3.45 and verbal interpretation of Strongly Agree as rank 1; it follows by social with a weighted mean of 3.32 and a verbal interpretation of Strongly Agree and rank 2; Economic with 3.09 weighted mean and verbal interpretation of Agree as rank 3.

Table 5. There was a significant relationship in terms of age supported by the result of the computed $p$-value of 0.023 .

Table 5: Test of Hypothesis in Terms of Age

\begin{tabular}{|l|c|c|c|c|c|}
\hline Respondents & df & $\boldsymbol{p}$-Value & Remarks & Decision & Conclusion \\
\hline Age & 10 & 0.023 & Less than & Reject HO & Significant Relationship \\
\hline
\end{tabular}

There was a significant relationship in terms of age; the finding was supported by the result of the computed $p$-value of 0.023 , which is less than 0.05 . The hypothesis of a significant relationship was rejected (HO). This result implies that age has a significant correlation to the impact of water hyacinth.

Table 6. There was no significant relationship in terms of gender supported by the result of the computed $p$-value of 0.396 .

Table 6: Test of Hypothesis in Terms of Gender

\begin{tabular}{|l|c|c|c|c|c|}
\hline Respondents & df & $\boldsymbol{p}$-Value & Remarks & Decision & Conclusion \\
\hline Gender & 2 & 0.396 & Greater than & Accept HO & No Significant Relationship \\
\hline
\end{tabular}

There was no significant relationship in terms of gender; the finding was supported by the result of the computed $p$-value of 0.396, which is greater than 0.05. The hypothesis of a significant relationship was accepted (HO). This finding implies that gender has no significant correlation to the impact of water hyacinth.

Table 7. There was no significant relationship in terms of civil status supported by the result of the computed $p$-value of 0.154 .

Table 7: Test of Hypothesis in Terms of Civil Status

\begin{tabular}{|l|c|c|c|c|c|}
\hline Respondents & df & $\boldsymbol{p}$-Value & Remarks & Decision & Conclusion \\
\hline Civil Status & 4 & 0.154 & Greater than & Accept HO & No Significant Relationship \\
\hline
\end{tabular}

There was no significant relationship in terms of Civil Status; the finding was supported by the result of the computed $p$-value of 0.154 , which is greater than 0.05 . The hypothesis of a significant relationship was accepted (HO). This result implies that the civil status has no significant correlation to the impact of water hyacinth.

Table 8. There was no significant relationship in terms of monthly income supported by the result of the computed p-value of 0.509 .

Table 8: Test of Hypothesis in Terms of Monthly Income

\begin{tabular}{|l|c|c|c|c|c|}
\hline Respondents & df & $\boldsymbol{p}$-Value & Remarks & Decision & Conclusion \\
\hline Monthly Income & 10 & 0.509 & Greater than & Accept HO & No Significant Relationship \\
\hline
\end{tabular}

There was no significant relationship in terms of monthly income; the finding was supported by the result of the computed $p$-value of 0.509 , which is greater than 0.05 . The hypothesis of a significant relationship was accepted (HO). This finding implies that the monthly income has no significant correlation to the impact of water hyacinth.

Table 9 . There was no significant relationship in terms of barangay supported by the result of the computed $p$-value of 0.316 . 
Table 9: Test of Hypothesis in Terms of Barangay

\begin{tabular}{|l|c|c|c|c|c|}
\hline Respondents & df & $\boldsymbol{p}$-Value & Remarks & Decision & Conclusion \\
\hline Barangay & 4 & 0.316 & Greater than & Accept HO & No Significant Relationship \\
\hline
\end{tabular}

There was no significant relationship in terms of barangay; the finding was supported by the result of the computed $p$-value of 0.316 , which is greater than 0.05 . The hypothesis of a significant relationship was accepted (HO). This result implies that the barangay has no significant correlation to the impact of water hyacinth.

Table 10. There was no significant relationship in terms of employment status supported by the result of the computed p-value of 0.259 .

Table 10: Test of Hypothesis in Terms of Employment Status

\begin{tabular}{|l|c|c|c|c|c|}
\hline Respondents & df & $\boldsymbol{p}$-Value & Remarks & Decision & Conclusion \\
\hline Employment Statu\$ & 8 & 0.259 & Greater than & Accept HO & No Significant Relationship \\
\hline
\end{tabular}

There was no significant relationship in terms of employment status; the finding was supported by the result of the computed $p$-value of 0.259 , which is greater than 0.05 . The hypothesis of a significant relationship was accepted (HO). This finding implies that the employment status has no significant correlation to the impact of water hyacinth.

\section{Conclusion and Recommendation}

In the light of the findings made from this study, the conclusion drawn by the researchers on the areas of the impacts of water hyacinths livelihood programs to the selected barangay in Taguig City. The findings present that the water hyacinths livelihood program is beneficial to the residents of three barangay and advantageous to the environment of the City of Taguig. It has been considered as an employment generation program for the residents, particularly near the site of the shop, in making water hyacinth products. It has been useful to the economic dynamism of the City of Taguig since it helps boost their household earnings. Thus, it is decided that they will use water hyacinth as their source of income in their daily living and will be able for them to be employed.

The study attempted to determine the impact of the use of Water Hyacinths as a Form of Livelihood Programs in the Local Residents of Taguig City. In terms of the profile of the respondents, the majority of the respondents were from the age 25-34 years old with 28\%, whereas 53\% were female and $47 \%$ were male as of the gender. Based on the findings on civil status, the majority were married, which comprise $48 \%$ of the total respondents. In terms of monthly income, the majority are earning 10,001-20,000 pesos, which comprise $34 \%$ of total respondents. The majority of the respondents is residing in Bambang comprise 36\%. Lastly, the majority are employed, which comprise 51\% as of employment status.

In relation to the impact of the use of water hyacinths as a form of livelihood programs, the overall interpretation was Strongly Agree, where the overall weighted mean is $(x=3.32)$ within the social aspect. Most of the respondents rated economic as Agree where the (overall weighted $x=3.09$, while in terms of environmental, it was rated as Strongly Agree (overall weighted $x=3.45$ ).

The researchers recommend to the Local Residents of Taguig City to continuously produce innovative items to generate income by using water hyacinth. It is also recommended for the other communities, not only Taguig City, to help enlighten every reader about the remarkable effect and advantage of water hyacinth in high hopes after reading this study. In addition, it is not only the unemployed people who will be benefited but the whole community itself. Also, the use of water hyacinth by the people will be normalized as their livelihood program as a way for them to generate income.

In terms of the Taguig Tourist, this study will be helpful in promoting the water hyacinth that will catch the attention of tourists to visit the city of Taguig in order to witness how residents make the water hyacinth into something useful. As a result, the funds gathered in the city will be beneficial that will serve as an additional fund to improve infrastructure or to provide jobs for Taguig residents who are unemployed.

This study will serve as a way for LPU Manila students to create income by adapting our data and innovating water hyacinth. Furthermore, it is respectfully suggested that more respondents should be included in determining the average values of data better and produce more precise results while avoiding biases. Moreover, this study can be used as a 
reference in the conduct of their research. Also, this study will provide an excellent triumph for the school itself, its teachers and students, and a solid foundation for incoming students who decide to study in LPU; it is recommended that the study be resolved further.

\section{References}

Department of Science and Technology. (2012). DOST Launches Solution to the Water Hyacinth Problem. https:// www.dost.gov.ph/knowledge-resources/news/35-2012-news/238-dost-launches-solution-to-the-water-hyacinthproblem.html

Dersseh, M.G., Kibret, A.A., Tilahun, S.A., Worqlul, A.W., Moges, M.A., Dagnew, D.C., ... and Melesse, A.M. (2019). Potential of Water Hyacinth Infestation on Lake Tana, Ethiopia: A Prediction Using a Gis-Based Multi-Criteria Technique. Water, 11(9), 1921.

Haider, S.Z. (1989). Recent Work in Bangladesh on the Utilisation of Water Hyacinth. Recent Work in Bangladesh on the Utilisation of Water Hyacinth, (278).

Melican, N. (2012). MMDA Wages War on Water Hyacinths. Inquirer.Net. https://newsinfo.inquirer.net/147563/mmdawages-war-on-water-hyacinths

Philippine Statistics Authority. (2015). Total Population by Province, City, Municipality and Barangay. National Capital Region (NCR). https://www.psa.gov.ph/sites/default/files/attachments/hsd/pressrelease/NCR.xlsx

Tadili, J. (2012). DOST, MMDA Deploy 1st Locally-Made Water Hyacinth Harvester in Taguig. GMA News Online. https://www.gmanetwork.com/news/scitech/science/248544/dost-mmda-deploy-1st-locally-made-water-hyacinthharvester-in-taguig/story/

Villamagna, A. (2010). Ecological and Socio Economic Impacts of Invasive Water Hyacinth (Eichhornia Crassipes): A Review. Wiley Online Library. https://doi.org/10.1111/j.1365-2427.2009.02294.x

Cite this article as: Anissa Kyla R. Abenoja, Bryan Ivan A. Cleofe, Nicole Anne R. Mondero, Paula N. Rodriguez and Jefferson S. Marcelo (2021). Impacts of the Use of Water Hyacinths as a Form of Livelihood Programs in the Local Residents of Taguig City: Inputs for Tourism Entrepreneurship. International Journal of Tourism and Hospitality. 1(4), 23-29. doi: 10.51483/IJTH.1.4.2021.23-29. 